Bakolis, I., Heinrich, J., Zock, J.P., Norbäck, D., Svanes, C., Chen, C.M., Accordini, S., Verlato, G., Olivieri, M., Jarvis, D. House dust-mite allergen exposure is associated with serum specific IgE but not with respiratory outcomes. Indoor Air: 2015, 25(3), 235-244

\begin{tabular}{|l|l|}
$\begin{array}{l}\text { Postprint } \\
\text { Version }\end{array}$ & 1.0 \\
\hline Journal website & http://onlinelibrary.wiley.com/doi/10.1111/ina.12137/abstract \\
\hline Pubmed link & $\underline{\text { http://www.ncbi.nlm.nih.gov/pubmed/24920489 }}$ \\
\hline DOI & $10.1111 /$ ina.12137 \\
\hline
\end{tabular}

This is a NIVEL certified Post Print, more info at http://www.nivel.eu

\title{
House dust-mite allergen exposure is associated with serum specific IgE but not with respiratory outcomes
}

I. BAKOLIS ${ }^{1}$, J. HeINRICH ${ }^{2}$, J. P. ZOCK ${ }^{345}$, D. NORBÄCK ${ }^{6}$, C. SVANES ${ }^{7}$, C. M. CHEN ${ }^{8}$, S. ACCORDINI $^{9}$, G. VERLATO ${ }^{10}$, M. OLIVIERI ${ }^{11}$, D. JARVIS ${ }^{12}$

1. Small Area Health Statistics Unit, MRC-HPA Centre for Environment and Health, Department of Epidemiology and Biostatistics, School of Public Health, Imperial College London, London, UK

2. Helmholtz Zentrum München, German Research Centre for Environmental Health, Institute of Epidemiology I, Neuherberg, Germany

3. Centre for Research in Environmental Epidemiology (CREAL), Barcelona, Spain

4. Universitat Pompeu Fabra (UPF), Barcelona, Spain

5. CIBER Epidemiologia y Salud Pública (CIBERESP), Barcelona, Spain

6. The Department of Medical Science, Occupational and Environmental Medicine, Uppsala University, Uppsala, Sweden

7. Bergen Respiratory Research Group, Centre for International Health, University of Bergen, Bergen, Norway

8. Helmholtz Zentrum München, German Research Centre for Environmental Health, Institute of Epidemiology I, Neuherberg, Germany

9. Epidemiology and Medical Statistics, University of Verona, Verona, Italy

10. Epidemiology and Medical Statistics, University of Verona, Verona, Italy

11. Unit of Occupational Medicine, University Hospital of Verona, Verona, Italy

12. MRC-HPA Centre for Environment and Health, London, UK Respiratory Epidemiology and Public Health Group, National Heart and Lung Institute, Imperial College London, London, UK

\begin{abstract}
Exposure to house dust has been associated with asthma in adults, and this is commonly interpreted as a direct immunologic response to dust-mite allergens in those who are IgE sensitized to house dust-mite. Mattress house dust-mite concentrations were measured in a population-based sample of 2890 adults aged between 27 and 56 years living in 22 centers in 10 countries. Generalized linear mixed models were employed to explore the association of respiratory symptoms with house dust-mite concentrations, adjusting for individual and household confounders. There was no overall association of respiratory outcomes with measured house dust-mite concentrations, even in those who reported they had symptoms on exposure to dust and those who had physiciandiagnosed asthma. However, there was a positive association of high serum
\end{abstract}


Bakolis, I., Heinrich, J., Zock, J.P., Norbäck, D., Svanes, C., Chen, C.M., Accordini, S., Verlato, G., Olivieri, M., Jarvis, D. House dust-mite allergen exposure is associated with serum specific IgE but not with respiratory outcomes. Indoor Air: 2015, 25(3), 235-244

specific IgE levels to $\mathrm{HDM}\left(>3.5 \mathrm{kU}_{\mathrm{A}} / \mathrm{l}\right)$ with mattress house dust-mite concentrations and a negative association of sensitization to cat with increasing house dust-mite concentrations. In conclusion, there was no evidence that respiratory symptoms in adults were associated with exposure to house dustmite allergen in the mattress, but an association of house mite with strong sensitization was observed.

\section{Practical Implications}

In this general population sample of European adults, there was some evidence of an association of allergic sensitization with house dust-mite concentrations, but not with respiratory symptoms.

\section{INTRODUCTION}

Some adults with asthma report they develop symptoms of asthma on exposure to house dust, and this is commonly interpreted as a direct immunologic response to dust-mite allergens in those who are IgE sensitized to these allergens (Custovic et al., 1998). Observational studies that have examined the cross-sectional association of symptoms and current house dust-mite exposure in adults do not provide a consistent picture with reports of lower levels of sensitization and less wheeze in those who are exposed (Dharmage et al., 2001), a higher prevalence of cough and wheeze in those who are exposed at high levels, irrespective of whether individuals were sensitized to house dust-mite or not (Gehring et al., 2001), and no (Chan-Yeung et al., 1995) or some (Custovic et al., 1996) influence of exposure on severity of disease. This contrasts to findings in children, where exposure to house dust-mite has been related to the development of specific IgE sensitization to house dust-mite (Lau et al., 2000; Torrent et al., 2006) and an increased risk for asthma consequently (Sporik et al., 1990). These associations have been reported to be nonlinear and bell shaped (Cullinan et al., 2004; Holt and Thomas, 2005; Schram-Bijkerk et al., 2006).

The aim of this analysis is to utilize information collected as part of a large international observational multicenter study to explore, in adults, associations of respiratory symptoms, including severity of symptoms with mattress house dust-mite allergen levels. Our main hypothesis is that associations, if they exist, apart from the overall population are largely seen in those who are IgE sensitized to house dustmite, those that report they experience symptoms on exposure to dust, and those who have physician-diagnosed asthma.

\section{METHODS}

\section{Sample}

The methodology of the ECRHS II has been described elsewhere (European Community Respiratory Health Survey II Steering Committee, 2002). Briefly, ECRHS II was the 10-year follow-up of participants who had taken part in ECRHS I. In ECRHS I, conducted from 1992 to 1994, a random sample of adults aged 20-44 years had completed a postal survey following which a random subsample was 
Bakolis, I., Heinrich, J., Zock, J.P., Norbäck, D., Svanes, C., Chen, C.M., Accordini, S., Verlato, G., Olivieri, M., Jarvis, D. House dust-mite allergen exposure is associated with serum specific IgE but not with respiratory outcomes. Indoor Air: 2015, 25(3), 235-244

invited for further investigation (extended questionnaires, venepuncture for later measurement of serum specific IgE to four major allergens, and measurement of bronchial reactivity). As part of ECRHS II, conducted in 2000-2002, 29 centers recontacted all individuals to undergo similar detailed investigations, and in 22 of these centers, (10 countries) a subsample was visited at home to assess home exposures and to obtain a mattress dust sample. The objective was to assess 200 homes per center, with home visits occurring as soon as possible after clinical assessment. Priority was given to participants who had not moved home between 1992/4 and 2000/2 and who, in 1992/4, provided a blood sample for serum specific IgE testing.

Within the ECRHS, a sample of adults with symptoms suggestive of asthma at ECRHS I has been followed up (if they had not already been selected within the random sample), and their information has been included in previous reports (Zock et al., 2006). For the purposes of this analysis which is based on a representative sample of the population, this 'enriched symptomatic group' is not included at any point.

\section{Dust sampling}

Between July 2000 and November 2002, homes were visited, and a $1 \mathrm{~m}^{2}$ area of the mattress was hoovered for 2 min to collect a sample of dust using a dust collection filter (ALK-Abello, Hørsholm, Denmark) as previously described (Zock et al., 2006). Samples were frozen for $24 \mathrm{~h}$ (to kill mites) and stored at room temperature until transportation to a central laboratory. Sieved dust was tested for Der p1, Der f1, and Der 2 using mAb ELISA (Indoor Biotechnologies, Cardiff, UK). The concentration of Der 1 allergens was calculated by summing Der p1 and Der f1 concentrations and considering undetectable levels below the limit of $0.1 \mu \mathrm{g} / \mathrm{g}$. The distribution of house dust-mite (and cat) allergens in these homes has been reported elsewhere (Zock et al., 2006). Sampling was conducted after the clinical examination (median time between the two 162 days, IQR 62-225 days).

\section{Asthma score}

A continuous measure of asthma symptoms (asthma score) was derived (Sunyer et al., 2007). It is the sum of positive responses to questions regarding the following symptoms in the last 12 months: wheeze with breathlessness, chest tightness, attack of shortness of breath (SOB) coming on at rest, SOB after exercise, and being woken by SOB.

\section{Total and specific IgE}

Serum total IgE and specific IgE to cat, house dust-mite (Dermatophagoides pteronyssinus), Cladosporium, and timothy grass were measured using the Pharmacia CAP System (Pharmacia Diagnostics AB, Uppsala, Sweden). 
Bakolis, I., Heinrich, J., Zock, J.P., Norbäck, D., Svanes, C., Chen, C.M., Accordini, S., Verlato, G., Olivieri, M., Jarvis, D. House dust-mite allergen exposure is associated with serum specific IgE but not with respiratory outcomes. Indoor Air: 2015, 25(3), 235-244

\section{Lung function}

Each participant was given up to nine attempts to provide two technically satisfactory forced expiratory maneuvers. The highest recorded $\mathrm{FEV}_{1}$ and FVC were used to derive age-sex-height-standardized residuals based on prediction equations from Quanjer (FEV 1 , FVC, FVC/FEV $)_{1}$ (Quanjer et al., 1994).

\section{Bronchial challenge}

Bronchial responsiveness (BHR) to methacholine was measured using a dosing schedule that delivered methacholine to a maximum dose of $1 \mathrm{mg}$. Methacholine was delivered via a Mefar dosimeter (Mefar, Bovezzo, Italy), forced expiratory volume in one-s (FEV1), recorded 2 min after each inhalation, and the test stopped when either a 20\% fall in FEV1 had been achieved or the final dose given. BHR is summarized as a 'slope' measure devised for use in the ECRHS (Chinn et al., 1999, 2005) and analyzed by multiple regression with a low slope indicative of high BHR, with values ranging from 1 to 20 (Chinn et al., 1997).

\section{Statistical analysis}

Concentrations of Der 1 (Der p1 plus Der f1) had highly positively skewed distributions, with almost a third below the detection limit of $0.1 \mu \mathrm{g} / \mathrm{g}$. Data were therefore divided into undetectable $(<0.1 \mu \mathrm{g} / \mathrm{g})$ and four quartile groups of detectable concentrations for each allergen (Der 1: 0.1-0.75, 0.76-4.01, 4.02-16.3, $>16.3 \mu \mathrm{g} / \mathrm{g}$ ). Analytic results of Der 1 values below the level of detection (LOD) $(<0.1 \mu \mathrm{g} / \mathrm{g})$ were arbitrarily given a value of $0.05 \mu \mathrm{g} / \mathrm{g}(1 / 2 \times \mathrm{LOD} ; n=928)$.

The association of asthma score with exposure to concentrations of Der 1 controlling for personal factors (age, gender, and smoking status as pack years) and for household variables (keeping a cat or dog, age of the mattress, presence of mold in bedroom, presence of damp in bedroom, household density, age of home) was assessed using a random intercept negative binomial model set to take account of clustering of individuals within centers. Asthma score is an ordinal score with a majority of zeros, so the negative binominal regression model, which allows for extra-Poisson variation, is the most appropriate for modeling this score (Jacquemin et al., 2009).

The association of house dust-mite concentrations with IgE sensitization to house dust-mite, grass, cat, and to any of the three was assessed using generalized linear mixed models (GLMM) controlling for the same personal and household factors. Similar analyses were conducted to examine associations with geometric mean total IgE, BHR, age-sex-height-standardized residuals of FEV1, age-sex-heightstandardized residuals of FVC, and age-sex-height-standardized residuals of FEV1/FVC.

These analyses were repeated but confined to the following subgroups (i) IgE sensitized to house dust-mite $(n=409)$ (ii) those reporting any symptoms on exposure to dust ( $n=780$; when you are in a dusty part of the house, or near pillows 
Bakolis, I., Heinrich, J., Zock, J.P., Norbäck, D., Svanes, C., Chen, C.M., Accordini, S., Verlato, G., Olivieri, M., Jarvis, D. House dust-mite allergen exposure is associated with serum specific IgE but not with respiratory outcomes. Indoor Air: 2015, 25(3), 235-244

or duvets, do you ever 1. start to cough? 2. Start to wheeze? 3. Get a feeling of nivel tightness in your chest? 4 . Start to feel short of breath? 5 . Get a runny or stuffy nose or start to sneeze? 6. Get itchy or watering eyes?), and (iii) those with physiciandiagnosed asthma ( $n=490$; have you ever had asthma and if was this confirmed by a doctor?). In addition, effect modification of the association of respiratory outcomes with house dust-mite concentrations with each of these factors in the complete sample was assessed by inclusion of an interaction term (all $P$ values $<0.05$, data not shown).

A meta-regression technique was also employed for testing the statistical significance of the trend of the association of respiratory outcomes with house dust- mite concentrations between centers. Departure from linearity of observed associations was tested with the use of generalized additive mixed models (GAMM).

Statistical analyses were conducted using STATA 10 (Stata Corporation, College Station, TX, USA) with generalized additive mixed models also performed in R (http://www.r-project.org/).

In all centers, permission to conduct this study was obtained from appropriate local ethics committees.

\section{RESULTS}

\section{Participants}

The ECRHS II survey included 7123 randomly selected individuals aged between 27 and 56 years living in 22 centers in 10 countries (Belgium - two centers, Germany two centers, Spain - five centers, Italy - three centers, France - two centers, UK two centers, Sweden - three centers, and one center in each of Iceland, Switzerland, and Estonia). Of these, 3414 had their mattress sampled and 2890 had sufficient dust for analysis for house dust-mite. Compared to the 4233 without house dust-mite measures, the final sample of 2890 was younger (mean age 43.7 vs. 41.9 years $P<$ 0.001 ) but there were no differences in gender (proportion male $46.5 \%$ vs. $48.1 \% P=$ 0.199), smoking behavior (proportion of current smokers $29.1 \%$ vs. $29.8 \% P=$ 0.163 ), and symptoms (proportion reporting wheeze in the last year $19.7 \%$ vs. $20.4 \%$ $P=0.472$ ). Asthma score and severity were similar ( $P$-values of chi-square test $>0.1)$.

Table 1 presents demographic data of those included in this analysis and descriptive statistics for the outcomes considered.

\section{[TABLE 1]}

\section{Asthma score}

There was no evidence of an association of asthma score with house dust-mite concentrations in the general population sample. In addition, there was no association of asthma score with house dust-mite concentrations in those IgE sensitized to house dust-mite, in those reporting any symptoms on exposure to dust, or in those with 
Bakolis, I., Heinrich, J., Zock, J.P., Norbäck, D., Svanes, C., Chen, C.M., Accordini, S., Verlato, G., Olivieri, M., Jarvis, D. House dust-mite allergen exposure is associated with serum specific IgE but not with respiratory outcomes. Indoor Air: 2015, 25(3), 235-244

physician-diagnosed asthma (Table 2). There was no evidence of nonlinear nivel associations when generalized additive mixed models were used (all $P$-values $>0.1$ ). No associations were observed when Der 2, Der p1 only, and Der f1 only exposure assessment was employed (data not shown).

\section{[TABLE 2]}

\section{IgE sensitization, lung function and BHR}

In unadjusted and adjusted analyses, specific IgE sensitization to HDM (defined by specific IgE titer above $0.35 \mathrm{kU}_{\mathrm{A}} / \mathrm{l}$ ) was not associated with house dust-mite concentrations in mattress dust (Table 3). Meta-regression showed no trend for an increase in prevalence of sensitization to HDM with increasing house dust-mite concentrations using this cutoff (Figure 1). However, when sensitization was defined as house dust-mite specific IgE titers above $0.7 \mathrm{kU} / \mathrm{l}$ or in other analysis with a cutoff above $3.5 \mathrm{kU}_{\mathrm{A}} / \mathrm{l}$ (i.e., participants were strongly sensitized against HDM), there was evidence for increasing prevalence of sensitization with higher mattress dust HDM concentrations (Table 3) in both unadjusted and adjusted analyses. Study participants with these high levels of specific IgE to HDM came mainly from France, UK, and Belgium (Table S1; see online supporting information http://onlinelibrary.wiley.com/journal/10.1111/\%28ISSN\%291600-0668). Due to the small numbers involved, we could not explore this further.

\section{[FIGURE 1.]}

Fixed and random effect meta-analysis of the relationship between IgE sensitization to house dust-mite (HDM) and Der 1 allergen levels adjusted for smoking status and household variables (cut-off point of IgE level to $\mathrm{HDM}>0.35 \mathrm{kU}_{\mathrm{A}} / \mathrm{l}$ and $0.70 \mathrm{kU}_{\mathrm{A}} / \mathrm{l}$ )

In both unadjusted and adjusted analyses, there was strong evidence that participants with higher mattress HDM concentrations were less likely to be sensitized to cat, irrespective of the cutoff used to define sensitization $\left(0.35 \mathrm{kU}_{\mathrm{A}} / \mathrm{l}, 0.70 \mathrm{kU}_{\mathrm{A}} / \mathrm{l}\right.$, and 3.5 $\mathrm{kU}_{\mathrm{A}} / \mathrm{l}$ ) (all $P$ for trend $<0.005$ ) (Table 3 ). Meta-regression could only be conducted using information from some centers (because of the low prevalence of cat sensitization in the others). Using this form of analysis, no significant associations were observed (see Figures S1-S3).

House dust-mite concentrations were not associated with specific IgE sensitization to grass pollen (cutoff points $>0.35 \mathrm{kU}_{\mathrm{A}} / \mathrm{l}, 0.70 \mathrm{kU}_{\mathrm{A}} / \mathrm{l}$, and $3.5 \mathrm{kU}_{\mathrm{A}} / \mathrm{l}$; $P$ for trend 0.29 , $0.28,0.11$, respectively, to different cutoff points; Table S2) and to 'atopy' (defined as sensitization to at least one of the HDM, cat or grass pollen ( $P$ for trend $0.84,0.76$, 0.38 , respectively, to different cutoff points) (Table 3 ). There was no evidence that the association of IgE to cat or grass pollen with HDM concentrations was nonlinear (GAMM model $P$-values $>0.1$ ).

There was no significant association of total IgE with house dust-mite concentrations (Table 3). Furthermore, there was no evidence that lung function (FEV1, FVC or FEV/FVC) varied with HDM concentrations in our general population sample or in 
Bakolis, I., Heinrich, J., Zock, J.P., Norbäck, D., Svanes, C., Chen, C.M., Accordini, S., Verlato, G., Olivieri, M., Jarvis, D. House dust-mite allergen exposure is associated with serum specific IgE but not with respiratory outcomes. Indoor Air: 2015, 25(3), 235-244

our subsamples (sensitized to house dust-mite, reported any symptoms on exposure to dust, asthma diagnosed by a physician) (Table 4). None of these associations (total IgE, lung function) were nonlinear (GAMM model $P$-values $>0.1$ ). As reported previously (Chinn et al., 2007), no association of BHR with HDM concentrations was observed.

No difference in overall results was observed when we restricted our analysis to those who had not moved home in the last 8 years, or when house dust-mite concentrations were considered as a binary exposure (detectable vs. undetectable; data not shown).

It could be argued that within these analyses, we have over-adjusted for factors that are on the causal pathway. Age of home and age of mattress are two such factors and we reran our analyses omitting these variables from our confounders list. No substantial changes in estimates were observed (data not shown).

In view of the unexpected strong negative association of cat sensitization with mattress HDM level, we added mattress cat allergen level as a confounder to relevant models, but this made little material difference to the estimates observed (data not shown).

Finally, no statistically significant $(P<0.05)$ associations were observed when current wheeze, doctor-diagnosed asthma and self-reported current use of asthma medication, and a combination of the above three (yes to at least one of these three symptoms) were used (data not shown).

\section{DISCUSSION}

In this large multicenter international study of middle-aged adults, we have found no association of a wide range of respiratory outcomes (asthma, BHR, lung function) with measured mattress house dust-mite concentrations. Even though we anticipated that associations may be limited to those who had serological evidence of allergy to house dust-mite, this was not the case. However, there was evidence that the prevalence of sensitization to house dust-mite when defined with a cutoff above that often used in epidemiology was (i.e., IgE levels above $3.5 \mathrm{kU}_{\mathrm{A}} / \mathrm{l}$ ) more prevalent with increasing house dust-mite allergen levels.

Participants in our survey were a subsample of a large representative sample of the population in each center and were similar in most respects to the complete study population. Information on respiratory symptoms, measurement of lung function, and collection of dust samples was all collected following a common standardized protocol. Serum samples for measurement of specific IgE, and dust samples for house dust-mite concentrations, were analyzed in a single central laboratory. We have analyzed this large multicenter data set with the use of multilevel modeling which accounts for within-center and between-center variation. Multilevel modeling is often considered superior to random effect meta-analysis (Severiens and ten Dam, 1998; Swanborn and de Glopper, 1999) providing more accurate standard error estimates (Bateman and Jones, 2003; Hox, 2010). It is more flexible as it can include 
Bakolis, I., Heinrich, J., Zock, J.P., Norbäck, D., Svanes, C., Chen, C.M., Accordini, S., Verlato, G., Olivieri, M., Jarvis, D. House dust-mite allergen exposure is associated with serum specific IgE but not with respiratory outcomes. Indoor Air: 2015, 25(3), 235-244

ordinal exposures (as we have used here) and complex interaction terms (Whitehead niver et al., 2001). Even using this widely applied method, we have been unable to observe strong or consistent associations for a wide range of respiratory outcomes (asthma, BHR, lung function).

There was no evidence of an association of asthma symptoms, as measured by asthma score. We also tested for wheeze, physician-diagnosed asthma, and current use of asthma medication, and we found similar non-statistically significant results. However, there was some evidence that exposure was associated with serum specific sensitization. This outcome variable is often investigated as a dichotomous variable with a cutoff of $0.35 \mathrm{kU}_{\mathrm{A}} / \mathrm{l}$ (Chinn et al., 1999; Gergen and Turkeltaub, 1992; Sears et al., 1989). This cutoff is often criticized as not being clinically relevant, and we have repeated analyses using higher titers to define sensitization, and associations can indeed be seen (Simpson et al., 2005; Wickman et al., 2005).

Skewness in the Der 1 levels and small numbers of individuals with severe asthma symptoms in our sample could have resulted to our null significant findings. However, post hoc power calculations with the use of the STATA command simsam (Hooper, 2013) showed that we had $80 \%$ power to detect an odds ratio of 1.3 when we compared individuals with undetectable Der 1 levels $\left(n_{1}=928\right)$ with those at the highest quartile of Der 1 levels in our sample $\left(n_{2}=483\right)$. We assumed a logistic regression model with disease prevalence of $15 \%$ at the $5 \%$ level of significance (Table S4).

We found evidence of a negative association of sensitization to cat (for all cutoffs) and mattress HDM levels. This was only seen in analyses employing multilevel modeling, because the low prevalence of sensitization in some centers was difficult to explore in further detail. We know of no biological reason why exposure to house dust-mite should protect against sensitization to cat and have not found any other studies reporting such an association. In post hoc analyses, we included level of cat allergen as a potential confounder, but this did not alter effect estimates. In a subsample of participants $(n=972)$, endotoxin levels were measured - but there was no correlation between mattress HDM and mattress endotoxin levels [correlation coefficient $(r)=0.05]$. There was no evidence that keeping a cat was more (or less) common in those with higher HDM levels. Therefore, until there is evidence to the contrary, the observation of lower levels of cat sensitization with mattress HDM levels should be interpreted with caution.

We recognize that the gold standard method to assess a causal relationship between dust-mite concentrations and respiratory disease is randomised controlled trials where the intervention leads to a reduction in exposure. However, a systematic review and meta-analysis of 54 controlled randomized trials has been conducted showing that there is no amelioration of symptoms in atopic or asthmatics with reduced exposure (relative risk was 1.01: 95\% CI 0.80-1.27) (Gotzsche and Johansen, 2008). Two studies that found positive results were excluded from this meta-analysis. The reasons for that were that one study was not blinded, and the positive results for these subjective outcomes were obtained through telephone 
Bakolis, I., Heinrich, J., Zock, J.P., Norbäck, D., Svanes, C., Chen, C.M., Accordini, S., Verlato, G., Olivieri, M., Jarvis, D. House dust-mite allergen exposure is associated with serum specific IgE but not with respiratory outcomes. Indoor Air: 2015, 25(3), 235-244

interviews (Morgan et al., 2004), and the other study did not provide sufficient evidence of how many individuals were allergic to mites (Krieger et al., 2005).

Our study is cross-sectional and is based on single measures of exposure in a single indoor location at a single time-point. As such, it has limitations. We measured mattress dust samples only, and we cannot exclude the possibility that measures from other indoor locations may have revealed associations. Mattress levels do have moderate correlations with levels in other parts of the home (Dharmage et al., 1999; Luczynska et al., 1998; Mihrshahi et al., 2002; Moscato et al., 2000), and a single measure of mattress HDM has been shown to be a fair proxy for a 1-year exposure (Heinrich et al., 2003). In one ECRHS center (Erfurt), mattress dust samples were compared with dust collection 6 years before. The Crude Spearman's rank correlation coefficients between the two measurements taken in 1995/96 and 2000/01 ranged from 0.32 to 0.61 for the dust-mites allergens and were higher if measurements were performed on the same floor or the same mattress at both sampling time-points. However, we cannot assume that the levels of HDM seen in our study reflect those experienced over the lifetime of our participants. In addition, Tovey \& Marks (Tovey et al., 2013) have challenged the commonly accepted view that HDM allergen levels in mattress dust give the best proxy for HDM airborne allergen exposure and have shown that most exposure occurs at incidental moments in many other domestic locations and not during the night while sleeping on the mattress. The observed lack of association of outcomes with mattress levels in our study may be a consequence of this.

Our cross-sectional study cannot address the biases that may be introduced if participants with symptoms take measures to reduce their exposure to allergens in their mattress. In our study, one in five (22.5\%) of participants reported making some active measure to reduce exposure to house dust-mite (either changing floor coverings, bought a new carpet for the room they use most, use of antidust-mite sprays, use of allergy proof mattress). Exclusion of these subjects from analyses made no material difference to the results obtained (data not shown), but we cannot rule out that our findings are biased toward the null by participants with symptoms and allergy taking active measures to reduce allergen exposure.

Concentrations of house dust-mite in our study vary substantially between regions, and it is possible that associations can only be observed when levels are high. However, even in centers with the higher concentrations of mattress house dust-mite, there was no evidence that associations existed with asthma score (Figure S4), lung function, and BHR (data not shown).

In conclusion, in a large international cross-sectional survey of adults, there was no evidence that symptoms of asthma, lung function, or bronchial reactivity were associated with exposure to levels of house dust-mite allergen in the mattress. These null findings are related to an adult population and could be different for children in whom house dust-mite avoidance methods may still be an important component of multifaceted intervention. There was evidence of an association of house dust-mite concentrations with high levels of serum specific IgE to HDM. 
Bakolis, I., Heinrich, J., Zock, J.P., Norbäck, D., Svanes, C., Chen, C.M., Accordini, S., Verlato, G., Olivieri, M., Jarvis, D. House dust-mite allergen exposure is associated with serum specific IgE but not with respiratory outcomes. Indoor Air: 2015, 25(3), 235-244

\section{SUPPORTING INFORMATION Description}

Table S1. Percentage of people with IgE titer levels (cutoff point of IgE level above $0.35 \mathrm{kU}_{\mathrm{A}} / \mathrm{l}, 0.70 \mathrm{kU}_{\mathrm{A}} / \mathrm{l}$ and $3.5 \mathrm{kU}_{\mathrm{A}} / \mathrm{l}$ ) considered as positive to House dust-mite (HDM) and Cat.

Table S2. Unadjusted and adjusted associations (95\% CI) of specific IgE titer to grass pollen per one level increase of Der 1 allergen levels in mattress dust.

Table S3. Percentages (\%) of asthma score for each category of Der 1 allergen levels in mattress dust.

Table S4. Estimation of power for different effect sizes and different prevalence of potential respiratory and allergic outcomes at the $5 \%$ level of significance. We are comparing two groups in a logistic regression analysis (unbalanced size of groups; $n_{1}$ $=928$ and $n_{2}=483$ ). Power calculations are employed with the use of simsam command in STATA (Hooper R., 2013).

Figure S1. Fixed and random effect meta-analysis of the relationship between IgE sensitization to cat and Der 1 allergen levels adjusted for smoking status and household variables (cut-of point of IgE level to cat $>0.35 \mathrm{kU}_{\mathrm{A}} / \mathrm{l}$ ).

Figure S2. Fixed and random effect meta-analysis of the relationship between IgE sensitization to cat and Der 1 allergen levels adjusted for smoking status and household variables (cut-of point of IgE level to cat $>0.70 \mathrm{kU}_{\mathrm{A}} / \mathrm{l}$ ).

Figure S3. Fixed and random effect meta-analysis of the relationship between IgE sensitization to cat and Der 1 allergen levels adjusted for smoking status and household variables (cut-of point of IgE level to cat $>3.5 \mathrm{kU}_{\mathrm{A}} / \mathrm{l}$ ).

Figure S4. Fixed and random effect meta-analysis of the relationship between asthma score (log linear) and Der 1 allergen levels adjusted for smoking status and household variables.

\section{REFERENCES}

Bateman, I.J. and Jones, A.P. (2003) Contrasting conventional with multi-level modeling approaches to meta-analysis: expectation consistency in U.K. woodland recreation values, Land Econ., 79, 235-258.

Chan-Yeung, M., Manfreda, J., Dimich-Ward, H., Lam, J., Ferguson, A., Warren, P., Simons, E., Broder, I., Chapman, M. and Platts-Mills, T. (1995) Mite and cat allergen levels in homes and severity of asthma, Am. J. Respir. Crit. Care Med., 152, 1805-1811.

Chinn, S., Arossa, W.A., Jarvis, D.L., Luczynska, C.M. and Burney, P.G. (1997) Variation in nebulizer aerosol output and weight output from the Mefar dosimeter: implications for multicentre studies, Eur. Respir. J., 10, 452-456.

Chinn, S., Burney, P., Sunyer, J., Jarvis, D. and Luczynska, C. (1999) Sensitization to individual allergens and bronchial responsiveness in the ECRHS. European Community Respiratory Health Survey, Eur. Respir. J., 14, 876-884. 
Bakolis, I., Heinrich, J., Zock, J.P., Norbäck, D., Svanes, C., Chen, C.M., Accordini, S., Verlato, G., Olivieri, M., Jarvis, D. House dust-mite allergen exposure is associated with serum specific IgE but not with respiratory outcomes. Indoor Air: 2015, 25(3), 235-244

Chinn, S., Jarvis, D., Luczynska, C.M., Ackermann-Liebrich, U., Anto, J.M., Cerveri, I., de Marco, R., Gislason, T., Heinrich, J., Janson, C., Kunzli, N., Leynaert, B., Neukirch, F., Schouten, J.P., Sunyer, J., Svanes, C., Wjst, M. and Burney, P.G. (2005) An increase in bronchial responsiveness is associated with continuing or restarting smoking, Am. J. Respir. Crit. Care Med., 172, 956-961.

Chinn, S., Heinrich, J., Anto, J.M., Janson, C., Norback, D., Olivieri, M., Svanes, C., Sunyer, J., Verlato, G., Wjst, M., Zock, J.P., Burney, P.G. and Jarvis, D.L. (2007) Bronchial responsiveness in atopic adults increases with exposure to cat allergen, Am. J. Respir. Crit. Care Med., 176, 20-26.

Cullinan, P., MacNeill, S.J., Harris, J.M., Moffat, S., White, C., Mills, P. and Newman Taylor, A.J. (2004) Early allergen exposure, skin prick responses, and atopic wheeze at age 5 in English children: a cohort study, Thorax, 59, 855-861.

Custovic, A., Taggart, S.C., Francis, H.C., Chapman, M.D. and Woodcock, A. (1996) Exposure to house dust mite allergens and the clinical activity of asthma, J. Allergy. Clin. Immunol., 98, 64-72.

Custovic, A., Simpson, A., Chapman, M.D. and Woodcock, A. (1998) Allergen avoidance in the treatment of asthma and atopic disorders, Thorax, 53, 63-72.

Dharmage, S., Bailey, M., Raven, J., Cheng, A., Rolland, J., Thien, F., Forbes, A., Abramson, M. and Walters, E.H. (1999) Residential characteristics influence Der $p 1$ levels in homes in Melbourne, Australia, Clin. Exp. Allergy, 29, 461-469.

Dharmage, S., Bailey, M., Raven, J., Mitakakis, T., Cheng, A., Guest, D., Rolland, J., Forbes, A., Thien, F., Abramson, M. and Walters, E.H. (2001) Current indoor allergen levels of fungi and cats, but not house dust mites, influence allergy and asthma in adults with high dust mite exposure, Am. J. Respir. Crit. Care Med., 164, 65-71.

European Community Respiratory Health Survey II Steering Committee (2002) The European Community Respiratory Health Survey II, Eur. Respir. J., 20, 1071-1079.

Gehring, U., Heinrich, J., Jacob, B., Richter, K., Fahlbusch, B., Schlenvoigt, G., Bischof, W., Wichmann, H.E. and Indoor Factors Genetics in Asthma (INGA) Study Group (2001) Respiratory symptoms in relation to indoor exposure to mite and cat allergens and endotoxins. Indoor Factors and Genetics in Asthma (INGA) Study Group, Eur. Respir. J., 18, 555-563.

Gergen, P.J. and Turkeltaub, P.C. (1992) The association of individual allergen reactivity with respiratory disease in a national sample: data from the second National Health and Nutrition Examination Survey, 1976-80 (NHANES II), J. Allergy. Clin. Immunol., 90, 579588.

Gotzsche, P.C. and Johansen, H.K. (2008) House dust mite control measures for asthma, Cochrane Database Syst. Rev., (2), CD001187.

Heinrich, J., Holscher, B., Douwes, J., Richter, K., Koch, A., Bischof, W., Fahlbusch, B., Kinne, R.W., Wichmann, H.E. and INGA Study Group (2003) Reproducibility of allergen, endotoxin and fungi measurements in the indoor environment, J. Expo. Anal. Environ. Epidemiol., 13, 152-160.

Holt, P.G. and Thomas, W.R. (2005) Sensitization to airborne environmental allergens: unresolved issues, Nat. Immunol., 6, 957-960.

Hooper, R. (2013) Versatile sample-size calculation using simulation, Stata J., 13, 21-38. Hox, J.J. (2010) Multilevel Analysis: Techniques and Applications, London, Routledge. Jacquemin, B., Sunyer, J., Forsberg, B., Aguilera, I., Bouso, L., Briggs, D., de Marco, R., Garcia-Esteban, R., Heinrich, J., Jarvis, D., Maldonado, J.A., Payo, F., Rage, E., Vienneau, D. and Kunzli, N. (2009) Association between modelled traffic-related air pollution and asthma score in the ECRHS, Eur. Respir. J., 34, 834-842.

Krieger, J.W., Takaro, T.K., Song, L. and Weaver, M. (2005) The Seattle-King county healthy homes project: a randomized controlled trial of a community health worker intervention to decrease exposure to indoor asthma triggers, Am. J. Public Health, 95, 652-659.

Lau, S., Illi, S., Sommerfeld, C., Niggemann, B., Bergmann, R., von Mutius, E. and Wahn, U. (2000) Early exposure to house-dust mite and cat allergens and development of childhood asthma: a cohort study, Multicentre Allergy Study Group, Lancet, 356, 1392-1397.

Luczynska, C., Sterne, J., Bond, J., Azima, H. and Burney, P. (1998) Indoor factors associated with concentrations of house dust mite allergen, Der $p 1$, in a random sample of houses in Norwich, UK, Clin. Exp. Allergy, 28, 1201-1209. 
Bakolis, I., Heinrich, J., Zock, J.P., Norbäck, D., Svanes, C., Chen, C.M., Accordini, S., Verlato, G., Olivieri, M., Jarvis, D. House dust-mite allergen exposure is associated with serum specific IgE but not with respiratory outcomes. Indoor Air: 2015, 25(3), 235-244

Mihrshahi, S., Marks, G., Vanlaar, C., Tovey, E. and Peat, J. (2002) Predictors of high house dust mite allergen concentrations in residential homes in Sydney, Allergy, 57, 137-142.

Morgan, W.J., Crain, E.F., Gruchalla, R.S., O'Connor, G.T., Kattan, M., Evans, R., Stout, J., Malindzak, G., Smartt, E., Plaut, M., Walter, M., Vaughn, B. and Mitchell, H. (2004) Results of a home-based environmental intervention among urban children with asthma, N. Engl. J. Med., 351, 1068-1080.

Moscato, G., Perfetti, L., Galdi, E., Pozzi, V. and Minoia, C. (2000) Levels of house-dust-mite allergen in homes of nonallergic people in Pavia, Italy, Allergy, 55, 873-878.

Quanjer, P.H., Tammeling, G.J., Cotes, J.E., Pedersen, O.F., Peslin, R. and Yernault, J.C. (1994) Lung volumes and forced ventilatory flows. Work Group on Standardization of Respiratory Function Tests. European Community for Coal and Steel. Official position of the European Respiratory Society, Rev. Mal. Respir., 11(Suppl 3), 5-40.

Schram-Bijkerk, D., Doekes, G., Boeve, M., Douwes, J., Riedler, J., Ublagger, E., von Mutius, E., Budde, J., Pershagen, G., van Hage, M., Wickman, M., Braun-Fahrlander, C., Waser, M. and Brunekreef, B. and PARSIFAL study group (2006) Nonlinear relations between house dust mite allergen levels and mite sensitization in farm and nonfarm children, Allergy, 61, 640-647.

Sears, M.R., Herbison, G.P., Holdaway, M.D., Hewitt, C.J., Flannery, E.M. and Silva, P.A. (1989) The relative risks of sensitivity to grass pollen, house dust mite and cat dander in the development of childhood asthma, Clin. Exp. Allergy, 19, 419-424.

Severiens, S. and ten Dam, G. (1998) A multilevel meta-analysis of gender differences in learning orientations, Br. J. Educ. Psychol., 68, 595-608.

Simpson, A., Soderstrom, L., Ahlstedt, S., Murray, C.S., Woodcock, A. and Custovic, A. (2005) IgE antibody quantification and the probability of wheeze in preschool children, $\mathrm{J}$. Allergy. Clin. Immunol., 116, 744-749.

Sporik, R., Holgate, S.T., Platts-Mills, T.A. and Cogswell, J.J. (1990) Exposure to house-dust mite allergen (Der $\mathrm{pl}$ ) and the development of asthma in childhood. A prospective study, N. Engl. J. Med., 323, 502-507.

Sunyer, J., Pekkanen, J., Garcia-Esteban, R., Svanes, C., Kunzli, N., Janson, C., de Marco, R., Anto, J.M. and Burney, P. (2007) Asthma score: predictive ability and risk factors, Allergy, 62, 142-148.

Swanborn, M.S.L. and de Glopper, K. (Fall, 1999) Incidental word learning while reading: a meta-analysis, Rev. Educ. Res., 69, 261-285.

Torrent, M., Sunyer, J., Muñoz, L., Cullinan, P., Iturriaga, M.V., Figueroa, C., Vall, O., Taylor, A.N. and Anto, J.M. (2006) Early-life domestic aeroallergen exposure and IgE sensitization at age 4 years, J. Allergy. Clin. Immunol., 118, 742-748.

Tovey, E.R., Willenborg, C.M., Crisafulli, D.A., Rimmer, J. and Marks, G.B. (2013) Most personal exposure to house dust mite aeroallergen occurs during the day, PLoS One, 8, e69900.

Whitehead, A., Omar, R.Z., Higgins, J.P., Savaluny, E., Turner, R.M. and Thompson, S.G. (2001) Meta-analysis of ordinal outcomes using individual patient data, Stat. Med., 20, 2243-2260.

Wickman, M., Lilja, G., Soderstrom, L., van Hage-Hamsten, M. and Ahlstedt, S. (2005) Quantitative analysis of IgE antibodies to food and inhalant allergens in 4-year-old children reflects their likelihood of allergic disease, Allergy, 60, 650-657.

Zock, J.P., Heinrich, J., Jarvis, D., Verlato, G., Norback, D., Plana, E., Sunyer, J., Chinn, S., Olivieri, M., Soon, A., Villani, S., Ponzio, M., Dahlman-Hoglund, A., Svanes, C. and Luczynska, C. and Indoor Working Group of the European Community Respiratory Health Survey II (2006) Distribution and determinants of house dust mite allergens in Europe: the European Community Respiratory Health Survey II, J. Allergy. Clin. Immunol., 118, 682690. 
Bakolis, I., Heinrich, J., Zock, J.P., Norbäck, D., Svanes, C., Chen, C.M., Accordini, S., Verlato, G., Olivieri, M., Jarvis, D. House dust-mite allergen exposure is associated with serum specific IgE but not with respiratory outcomes. Indoor Air: 2015, 25(3), 235-244

\section{TABLES AND FIGURES}

Table 1. Description of sample

\begin{tabular}{|c|c|c|}
\hline & $\begin{array}{c}\text { Total with } \\
\text { information }\end{array}$ & \begin{tabular}{|c|} 
Proportion (\%) unless \\
otherwise stated
\end{tabular} \\
\hline Age (med, IQR) & 2890 & $\begin{array}{l}\text { Median: 44.4, IQR: } \\
\text { 31.6-53.7 }\end{array}$ \\
\hline Male & $1346 / 2890$ & 49.4 \\
\hline \multicolumn{3}{|l|}{ Asthma Score } \\
\hline 0 & $1990 / 2890$ & 68.8 \\
\hline 1 & $544 / 2890$ & 18.8 \\
\hline 2 & $201 / 2890$ & 6.9 \\
\hline 3 & $87 / 2890$ & 3.0 \\
\hline 4 & $44 / 2890$ & 1.5 \\
\hline 5 & $24 / 2890$ & 0.8 \\
\hline Wheeze & $571 / 2890$ & 19.7 \\
\hline Doctor diagnosed asthma & $251 / 2890$ & 8.6 \\
\hline Use of asthma medication & $112 / 2890$ & 3.8 \\
\hline $\begin{array}{l}\text { Yes to at least one of current wheeze, } \\
\text { doctor diagnosed asthma or use of } \\
\text { medication }\end{array}$ & $663 / 2890$ & 22.9 \\
\hline Symptoms on exposure to dust & $780 / 2890$ & 26.9 \\
\hline \multicolumn{3}{|l|}{ Smokers } \\
\hline Never & $1223 / 2890$ & 42.8 \\
\hline Ever & $821 / 2890$ & 28.4 \\
\hline Current & $842 / 2890$ & 29.1 \\
\hline IgE to house dust-mite $>0.35\left(\mathrm{kU}_{\mathrm{A}} / \mathrm{l}\right)$ & $409 / 2890$ & 14.1 \\
\hline IgE to grass $>0.35\left(\mathrm{kU}_{\mathrm{A}} / \mathrm{l}\right)$ & $400 / 2890$ & 13.8 \\
\hline IgE to cat >0.35 $\left(\mathrm{kU}_{\mathrm{A}} / \mathrm{l}\right)$ & $226 / 2890$ & 7.8 \\
\hline IgE to HDM, grass or cat $>0.35\left(\mathrm{kU}_{\mathrm{A}} / \mathrm{l}\right)$ & $725 / 2890$ & 25.0 \\
\hline IgE to house dust-mite $>0.70\left(\mathrm{kU}_{\mathrm{A}} / \mathrm{l}\right)$ & $302 / 2890$ & 10.4 \\
\hline IgE to grass $>0.70\left(\mathrm{kU}_{\mathrm{A}} / \mathrm{l}\right)$ & $334 / 2890$ & 11.5 \\
\hline IgE to cat $>0.70\left(\mathrm{kU}_{\mathrm{A}} / \mathrm{l}\right)$ & $159 / 2890$ & 5.5 \\
\hline IgE to HDM, grass or cat $>0.70\left(\mathrm{kU}_{\mathrm{A}} / \mathrm{l}\right)$ & $584 / 2890$ & 20.2 \\
\hline IgE to house dust-mite $>3.5\left(\mathrm{kU}_{\mathrm{A}} / \mathrm{l}\right)$ & $152 / 2890$ & 5.2 \\
\hline IgE to grass $>3.5\left(\mathrm{kU}_{\mathrm{A}} / \mathrm{l}\right)$ & $204 / 2890$ & 7.0 \\
\hline IgE to cat $>3.5\left(\mathrm{kU}_{\mathrm{A}} / \mathrm{l}\right)$ & $80 / 2890$ & 2.7 \\
\hline
\end{tabular}


Bakolis, I., Heinrich, J., Zock, J.P., Norbäck, D., Svanes, C., Chen, C.M., Accordini, S., Verlato, G., Olivieri, M., Jarvis, D. House dust-mite allergen exposure is associated with serum specific IgE but not with respiratory outcomes. Indoor Air: 2015, 25(3), 235-244

nive

\begin{tabular}{|l|l|l|}
\hline & \multicolumn{1}{|c|}{$\begin{array}{c}\text { Total with } \\
\text { information }\end{array}$} & $\begin{array}{l}\text { Proportion (\%) unless } \\
\text { otherwise stated }\end{array}$ \\
\hline IgE to HDM, grass or cat $>3.5\left(\mathrm{kU}_{\mathrm{A}} / \mathrm{l}\right)$ & $362 / 2890$ & 12.5 \\
\hline Geometric mean IgE & 2552 & $\begin{array}{l}\text { Geometric Mean: } 1.50 \\
(\mathrm{kU} / \mathrm{l})\end{array}$ \\
\hline Cat or dog in house & $914 / 2890$ & 31.6 \\
\hline Mold in bedroom & $199 / 2890$ & 6.8 \\
\hline Damp in bedroom & $142 / 2890$ & 4.9 \\
\hline House built before 1970 & $1383 / 2890$ & 47.8 \\
\hline Mattress $<1$ year old & $197 / 2890$ & 6.8 \\
\hline Household density & & Median: 0.7 \\
\hline Der 1 exposure $\mu \mathrm{g} / \mathrm{g}$ & 2852 & $\mathrm{IQR}: 0.3-1.3$ \\
\hline Undetectable & \multicolumn{2}{|l}{} \\
\hline $0.1-0.76$ & $928 / 2890$ & 32.1 \\
\hline $0.77-4.01$ & $487 / 2890$ & 16.8 \\
\hline $4.02-16.3$ & $507 / 2890$ & 17.5 \\
\hline$>16.3$ & $485 / 2890$ & 16.7 \\
\hline & $483 / 2890$ & 16.7 \\
\hline
\end{tabular}

Table 2. Adjusteda ratio of asthma score to Der 1 allergen levels in mattress dust

\begin{tabular}{|c|c|c|c|c|}
\hline & \begin{tabular}{|} 
All participants \\
in general \\
population $(n=$ \\
$2679)(95 \%$ \\
CI) $P$-value
\end{tabular} & $\begin{array}{c}\text { All } \\
\text { participants } \\
\text { sensitized to } \\
\text { HDM ( } n= \\
\text { 388) }(95 \% \text { CI) } \\
\text { P-value } \\
\end{array}$ & \begin{tabular}{|} 
All participants \\
reporting any \\
symptoms on \\
exposure to dust \\
$(n=725)(95 \%$ \\
CI) $P$-value \\
\end{tabular} & $\begin{array}{l}\text { All participants } \\
\text { with physician- } \\
\text { diagnosed } \\
\text { asthma }(\boldsymbol{n}= \\
233)(95 \% \mathrm{CI}) \\
\text { P-value } \\
\end{array}$ \\
\hline \multicolumn{5}{|c|}{ Asthma Score (adjusteda ratio) } \\
\hline Undetectable & \begin{tabular}{|l|}
1 (reference \\
group)
\end{tabular} & $\begin{array}{l}1 \text { (reference } \\
\text { group) }\end{array}$ & \begin{tabular}{|l}
1 (reference \\
group)
\end{tabular} & $\begin{array}{l}1 \text { (reference } \\
\text { group) }\end{array}$ \\
\hline $0.1-$ & $\begin{array}{l}0.98(0.79 \\
1.22) \\
0.916\end{array}$ & $\begin{array}{l}1.03(0.65, \\
1.63) \\
0.886\end{array}$ & $\begin{array}{l}0.92(0.68,1.23) \\
0.56\end{array}$ & $\begin{array}{l}1.25(0.91,1.72) \\
0.165\end{array}$ \\
\hline 0.77 & $\begin{array}{l}0.86(0.68, \\
1.07) \\
0.192\end{array}$ & $\begin{array}{l}0.84(0.52, \\
1.36) \\
0.496\end{array}$ & $\begin{array}{l}0.89(0.64,1.22) \\
0.47\end{array}$ & $\begin{array}{l}0.84(0.58,1.23) \\
0.380\end{array}$ \\
\hline $4.02-16.3$ & $\begin{array}{l}0.96(0.76, \\
1.20)\end{array}$ & $\begin{array}{l}1.05(0.65, \\
1.71)\end{array}$ & $\begin{array}{l}0.98(0.70,1.38) \\
0.93\end{array}$ & $\begin{array}{l}0.91(0.62,1.35) \\
0.673\end{array}$ \\
\hline
\end{tabular}


Bakolis, I., Heinrich, J., Zock, J.P., Norbäck, D., Svanes, C., Chen, C.M., Accordini, S., Verlato, G., Olivieri, M., Jarvis, D. House dust-mite allergen exposure is associated with serum specific IgE but not with respiratory outcomes. Indoor Air: 2015, 25(3), 235-244

\begin{tabular}{|c|c|c|c|c|}
\hline & $\begin{array}{c}\text { All participants } \\
\text { in general } \\
\text { population }(n= \\
2679)(95 \% \\
\text { CI) } P \text {-value }\end{array}$ & \begin{tabular}{|c} 
All \\
participants \\
sensitized to \\
HDM (n = \\
388) (95\% CI) \\
P-value
\end{tabular} & \begin{tabular}{|c|} 
All participants \\
reporting any \\
symptoms on \\
exposure to dust \\
$(n=725)(95 \%$ \\
CI) $P$-value
\end{tabular} & $\begin{array}{l}\text { All participants } \\
\text { with physician- } \\
\text { diagnosed } \\
\text { asthma ( } n= \\
233)(95 \% \mathrm{CI}) \\
\text { P-value }\end{array}$ \\
\hline & 0.722 & 0.819 & & \\
\hline$>16.3$ & $\begin{array}{l}0.94(0.74, \\
1.18) \\
0.619\end{array}$ & $\begin{array}{l}0.82(0.50, \\
1.34) \\
0.436\end{array}$ & $\begin{array}{l}1.08(0.78,1.49) \\
0.64\end{array}$ & $\begin{array}{l}1.26(0.87,1.82) \\
0.205\end{array}$ \\
\hline $\begin{array}{l}P \text { value for } \\
\text { trend }\end{array}$ & 0.567 & 0.485 & 0.741 & 0.647 \\
\hline $\begin{array}{l}I^{2} \text { for } \\
\text { heterogeneity } \\
\text { for trend }\end{array}$ & $12.9 \%$ & $0.0 \%$ & $-b$ & $-b$ \\
\hline
\end{tabular}

a Confounders are age, sex, and smoking status as pack years and for household variables (keeping a cat or dog, age of the mattress, presence of mold in bedroom, presence of damp in bedroom, household density, and age of home).

${ }^{b}$ We had limited observations to test for heterogeneity across centers.

Table 3. Unadjusted and adjusted associations (95\% CI) of specific IgEs, total IgE, and Bronchial responsiveness (BHR) with Der 1 allergen levels in mattress dust

\begin{tabular}{|c|c|c|}
\hline IgE to & Unadjusted odds ratio & Adjusteda odds ratio \\
\hline \multicolumn{3}{|l|}{ House dust-mite } \\
\hline$\left(\right.$ Cut off $\left.>0.35 \mathrm{kU}_{\mathrm{A}} / \mathrm{l}\right)$ & $(n=2608)$ & $(n=2419)$ \\
\hline Undetectable & 1 (reference group) & 1 (reference group) \\
\hline 0.1 to 0.76 & $1.43(0.95,2.15)$ & $1.22(0.80,1.87)$ \\
\hline 0.77 to 4.01 & $1.18(0.78,1.81)$ & $1.04(0.67,1.62)$ \\
\hline 4.02 to 16.3 & $1.29(0.84,1.97)$ & $1.05(0.66,1.65)$ \\
\hline$>16.3$ & $1.59(1.02,2.46)$ & $1.36(0.85,2.16)$ \\
\hline$P$ for trend & 0.130 & 0.393 \\
\hline \multicolumn{3}{|l|}{$\left(\right.$ Cut off $\left.>0.70 \mathrm{kU}_{\mathrm{A}} / \mathrm{l}\right)$} \\
\hline Undetectable & 1 (reference group) & 1 (reference group) \\
\hline $0.1-0.76$ & $1.72(1.07,2.77)$ & $1.47(0.89,2.42)$ \\
\hline $0.77-4.01$ & $1.62(1.00,2.62)$ & $1.42(0.85,2.35)$ \\
\hline $4.02-16.3$ & $1.70(1.04,2.78)$ & $1.38(0.82,2.33)$ \\
\hline$>16.3$ & $2.13(1.30,3.50)$ & $1.83(1.08,3.10)$ \\
\hline$P$ for trend & 0.014 & 0.071 \\
\hline \multicolumn{3}{|l|}{$\left(\right.$ Cut off $\left.>3.5 \mathrm{kU}_{\mathrm{A}} / \mathrm{l}\right)$} \\
\hline Undetectable & 1 (reference group) & 1 (reference group) \\
\hline
\end{tabular}


Bakolis, I., Heinrich, J., Zock, J.P., Norbäck, D., Svanes, C., Chen, C.M., Accordini, S., Verlato, G., Olivieri, M., Jarvis, D. House dust-mite allergen exposure is associated with serum specific IgE but not with respiratory outcomes. Indoor Air: 2015, 25(3), 235-244

\begin{tabular}{|c|c|c|}
\hline IgE to & Unadjusted odds ratio & Adjusteda odds ratio \\
\hline $0.1-0.76$ & $2.71(1.37,5.35)$ & $2.55(1.26,5.14)$ \\
\hline $0.77-4.01$ & $3.17(1.62,6.21)$ & $3.04(1.52,6.09)$ \\
\hline $4.02-16.3$ & $2.93(1.47,5.82)$ & $2.68(1.32,5.46)$ \\
\hline$>16.3$ & $3.53(1.77,7.02)$ & $3.26(1.60,6.67)$ \\
\hline$P$ for trend & $<0.001$ & 0.013 \\
\hline \multicolumn{3}{|l|}{ Cat } \\
\hline$\left(\right.$ Cut off $\left.>0.35 \mathrm{kU}_{\mathrm{A}} / \mathrm{l}\right)$ & $(n=2608)$ & $(n=2419)$ \\
\hline Undetectable & 1 (reference group) & 1 (reference group) \\
\hline $0.1-0.76$ & $1.17(0.80,1.71)$ & $1.11(0.74,1.64)$ \\
\hline $0.77-4.01$ & $0.69(0.45,1.07)$ & $0.63(0.40,1.00)$ \\
\hline $4.02-16.3$ & $0.73(0.47,1.14)$ & $0.72(0.46,1.14)$ \\
\hline$>16.3$ & $0.52(0.31,0.86)$ & $0.55(0.33,0.91)$ \\
\hline$P$ for trend & 0.003 & 0.005 \\
\hline \multicolumn{3}{|l|}{$\left(\right.$ Cut off $\left.>0.70 \mathrm{kU}_{\mathrm{A}} / \mathrm{l}\right)$} \\
\hline Undetectable & 1 (reference group) & 1 (reference group) \\
\hline $0.1-0.76$ & $0.65(0.40,1.06)$ & $0.64(0.39,1.04)$ \\
\hline $0.77-4.01$ & $0.58(0.35,0.96)$ & $0.50(0.29,0.85)$ \\
\hline $4.02-16.3$ & $0.52(0.30,0.90)$ & $0.54(0.31,0.92)$ \\
\hline$>16.3$ & $0.50(0.28,0.88)$ & $0.52(0.29,0.92)$ \\
\hline$P$ for trend & 0.005 & 0.006 \\
\hline \multicolumn{3}{|c|}{$\left(\right.$ Cut off $\left.>3.5 \mathrm{kU}_{\mathrm{A}} / \mathrm{l}\right)$} \\
\hline Undetectable & 1 (reference group) & 1 (reference group) \\
\hline $0.1-0.76$ & $0.63(0.33,1.17)$ & $0.57(0.30,1.09)$ \\
\hline $0.77-4.01$ & $0.38(0.18,0.79)$ & $0.33(0.15,0.73)$ \\
\hline $4.02-16.3$ & $0.41(0.19,0.85)$ & $0.42(0.19,0.88)$ \\
\hline$>16.3$ & $0.38(0.17,0.82)$ & $0.39(0.18,0.87)$ \\
\hline$P$ for trend & 0.001 & 0.001 \\
\hline \multicolumn{3}{|c|}{ Grass pollen or house dust-mite or cat } \\
\hline (Cut off $\left.>0.35 \mathrm{kU}_{\mathrm{A}} / \mathrm{l}\right)$ & $(n=2606)$ & $(n=2417)$ \\
\hline Undetectable & 1 (reference group) & 1 (reference group) \\
\hline $0.1-0.76$ & $1.32(0.98,1.76)$ & $1.20(0.88,1.63)$ \\
\hline $0.77-4.01$ & $1.05(0.78,1.41)$ & $0.95(0.69,1.31)$ \\
\hline $4.02-16.3$ & $1.11(0.82,1.50)$ & $1.00(0.72,1.38)$ \\
\hline$>16.3$ & $1.18(0.86,1.62)$ & $1.05(0.75,1.47)$ \\
\hline$P$ for trend & 0.617 & 0.840 \\
\hline \multicolumn{3}{|l|}{ (Cut off $\left.>0.70 \mathrm{kU}_{\mathrm{A}} / \mathrm{l}\right)$} \\
\hline
\end{tabular}


Bakolis, I., Heinrich, J., Zock, J.P., Norbäck, D., Svanes, C., Chen, C.M., Accordini, S., Verlato, G., Olivieri, M., Jarvis, D. House dust-mite allergen exposure is associated with serum specific IgE but not with respiratory outcomes. Indoor Air: 2015, 25(3), 235-244

\begin{tabular}{|c|c|c|}
\hline IgE to & Unadjusted odds ratio & ||Adjusteda odds ratio \\
\hline Undetectable & 1 (reference group) & 1 (reference group) \\
\hline $0.1-0.76$ & $1.22(0.90,1.65)$ & $1.10(0.79,1.53)$ \\
\hline 0.77-4.01 & $1.02(0.75,1.40)$ & $0.93(0.66,1.31)$ \\
\hline $4.02-16.3$ & $1.12(0.82,1.54)$ & $1.01(0.71,1.42)$ \\
\hline$>16.3$ & $1.08(0.78,1.51)$ & $0.98(0.68,1.40)$ \\
\hline$P$ for trend & 0.776 & 0.764 \\
\hline \multicolumn{3}{|l|}{$\left(\right.$ Cut off $\left.>3.5 \mathrm{kU}_{\mathrm{A}} / \mathrm{l}\right)$} \\
\hline $0.1-0.76$ & $1.05(0.72,1.52)$ & $0.95(0.64,1.42)$ \\
\hline $0.77-4.01$ & $0.94(0.64,1.38)$ & $0.84(0.56,1.27)$ \\
\hline 4.02 to 16.3 & $1.06(0.72,1.55)$ & $0.99(0.65,1.49)$ \\
\hline$>16.3$ & $0.85(0.56,1.29)$ & $0.77(0.49,1.21)$ \\
\hline \multirow[t]{2}{*}{$P$ for trend } & 0.577 & 0.386 \\
\hline & Unadjusted coefficient & Adjusteda coefficient \\
\hline Logarithmic total IgE & $(n=2605)$ & $(n=2416)$ \\
\hline Undetectable & |0 (reference group) & 0 (reference group) \\
\hline $0.1-0.76$ & $0.071(-0.06,0.14)$ & $0.04(-0.03,0.12)$ \\
\hline $0.77-4.01$ & $0.05(-0.02,0.12)$ & $0.02(-0.05,0.10)$ \\
\hline $4.02-16.3$ & $\mid-0.03(-0.04,0.11)$ & $0.08(-0.07,0.09)$ \\
\hline$>16.3$ & $0.05(-0.02,0.14)$ & $0.02(-0.06,0.11)$ \\
\hline$P$ for trend & 0.448 & 0.829 \\
\hline BHR slope & $\|(n=2070)$ & $(n=1906)$ \\
\hline Undetectable & |0 (reference group) & 0 (reference group) \\
\hline $0.1-0.76$ & $0.18(-0.13,0.51)$ & $0.12(-0.19,0.45)$ \\
\hline $0.77-4.01$ & $0.11(-0.21,0.43)$ & $0.12(-0.20,0.45)$ \\
\hline $4.02-16.3$ & $0.02(-0.30,0.35)$ & $-0.03(-0.36,0.29)$ \\
\hline$>16.3$ & $0.22(-0.11,0.56)$ & $0.20(0.13,0.54)$ \\
\hline$P$ for trend & 0.437 & 0.483 \\
\hline
\end{tabular}

${ }^{a}$ Confounders are age, sex, and smoking status as pack years and for household variables (keeping a cat or dog, age of the mattress, presence of mold in bedroom, presence of damp in bedroom, household density, and age of home). 
Bakolis, I., Heinrich, J., Zock, J.P., Norbäck, D., Svanes, C., Chen, C.M., Accordini, S., Verlato, G., Olivieri, M., Jarvis, D. House dust-mite allergen exposure is associated with serum specific IgE but not with respiratory outcomes. Indoor Air: 2015, 25(3), 235-244

Table 4. Adjusteda mean difference of $\mathrm{FEV}_{1}$ standardized residualsb per one category increase of Der 1 allergen levels in mattress dust

\begin{tabular}{|c|c|c|c|c|}
\hline 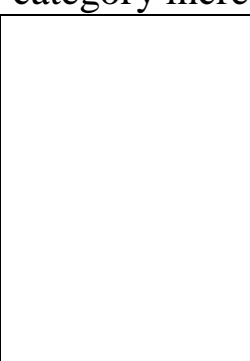 & \begin{tabular}{|c|} 
All \\
participants in \\
general \\
population $(n$ \\
$=2511)(95 \%$ \\
CI) $P$-value
\end{tabular} & \begin{tabular}{|c} 
All \\
participants \\
sensitized to \\
HDM ( $n=$ \\
377) (95\% CI) \\
P-value
\end{tabular} & \begin{tabular}{|c|} 
All participants \\
for those \\
reporting any \\
symptoms on \\
exposure to dust \\
$(n=687)(95 \%$ \\
CI) $P$-value
\end{tabular} & $\begin{array}{l}\text { All participants } \\
\text { with asthma } \\
\text { diagnosed by a } \\
\text { physician ( } n= \\
217)(95 \% \mathrm{CI}) \\
\text { P-value }\end{array}$ \\
\hline Undetectable & $\begin{array}{l}\text { Reference } \\
\text { group }\end{array}$ & $\begin{array}{l}\text { Reference } \\
\text { group }\end{array}$ & Reference group & Reference group \\
\hline $0.1-0.76$ & $\begin{array}{l}0.10(-0.02, \\
0.24) \\
0.122\end{array}$ & $\begin{array}{l}0.04 \\
(-0.33 .0 .43) \\
0.803\end{array}$ & $\begin{array}{l}0.15(-0.11,0.77) \\
0.67\end{array}$ & $\begin{array}{l}0.06(-0.42, \\
0.54) \\
0.804\end{array}$ \\
\hline $0.77-4.01$ & $\begin{array}{l}0.16(0.02, \\
0.30) \\
0.024\end{array}$ & $\begin{array}{l}0.13(-0.26 \\
0.52) \\
0.514\end{array}$ & $\begin{array}{l}0.12(-0.47,0.50) \\
0.09\end{array}$ & $\begin{array}{l}-0.28(-0.79 \\
0.22) \\
0.266\end{array}$ \\
\hline $4.02-16.3$ & $\begin{array}{l}0.17 \mathrm{c}(0.02, \\
0.32) \\
0.024\end{array}$ & $\begin{array}{l}0.11(-0.28 \\
0.51) \\
0.579\end{array}$ & $\begin{array}{l}0.33(-0.02,1.00) \\
0.09\end{array}$ & $\begin{array}{l}-0.09(-0.61 \\
0.43) \\
0.773\end{array}$ \\
\hline$>16.3$ & $\begin{array}{l}0.11(-0.04 \\
0.28) \\
0.159\end{array}$ & $\begin{array}{l}0.17(-0.23, \\
0.57) \\
0.406\end{array}$ & $\begin{array}{l}0.13(-0.45,0.54) \\
0.984\end{array}$ & $\begin{array}{l}-0.13(-0.68, \\
0.40) \\
0.443\end{array}$ \\
\hline $\begin{array}{l}P \text { value for } \\
\text { trend }\end{array}$ & 0.100 & 0.384 & 0.143 & 0.456 \\
\hline $\begin{array}{l}I^{2} \text { for } \\
\text { heterogeneity } \\
\text { of trend }\end{array}$ & $6.2 \%$ & $0.0 \%$ & $25.4 \%$ & $0.0 \%$ \\
\hline
\end{tabular}

a Confounders are smoking status as pack years and for household variables (keeping a cat or dog, age of the mattress, presence of mold in bedroom, presence of damp in bedroom, household density, and age of home).

b A man of age 50 and height 180 is predicted to have a FEV1 of 3.8 I using the Quanjer equation. If his observed FEV1 is $4 \mathrm{I}$, then the difference of observed FEV 1 - predicted FEV1 is $0.2 \mathrm{I}$. Following standardization (again using the standard deviation provided by Quanjer), his standardized residual is 0.38 . This means the difference of his measured and his predicted FEV1 is 0.38 standard deviations greater than the mean of all of these values.

c A coefficient of 0.17 in this table means that for a per one category increase in house dustmite levels; there is a change of 0.17 standard deviations in the difference between measured and predicted FEV1. 
Bakolis,1.,Heinnch, J.,Zoek, J.P., Norbäck, D., Svanes, C., Chen, C.M., Accordini, S., Verlato, G., Olivien, M., Jarvis, D. House dust-mite allergen exposure is associated with serum specific $\lg$ E but not with respiratory outcomes Indoor Air:2014

Fig. 1 Fixed and random effect meta-analysis ofthe relationship between lgE sensitization to house dust-mite (HDM) and Der 1 allergen levels adjusted for smoking status and household variables (cut-off point of lgE level to $\mathrm{HDM}>0.35 \mathrm{kUA} / 1$ and $0.70 \mathrm{kUA} / 1$ )

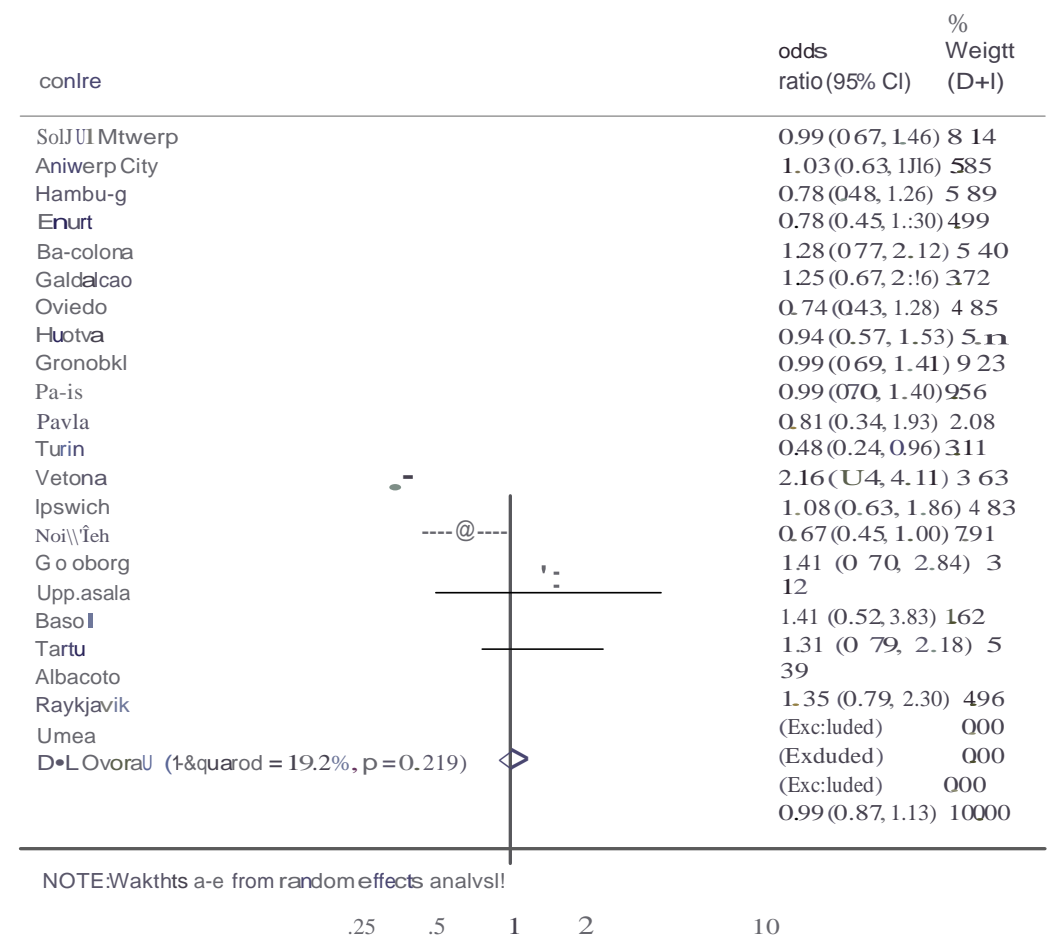

wt-off levelof IgE to HOM >0.35 KUIL

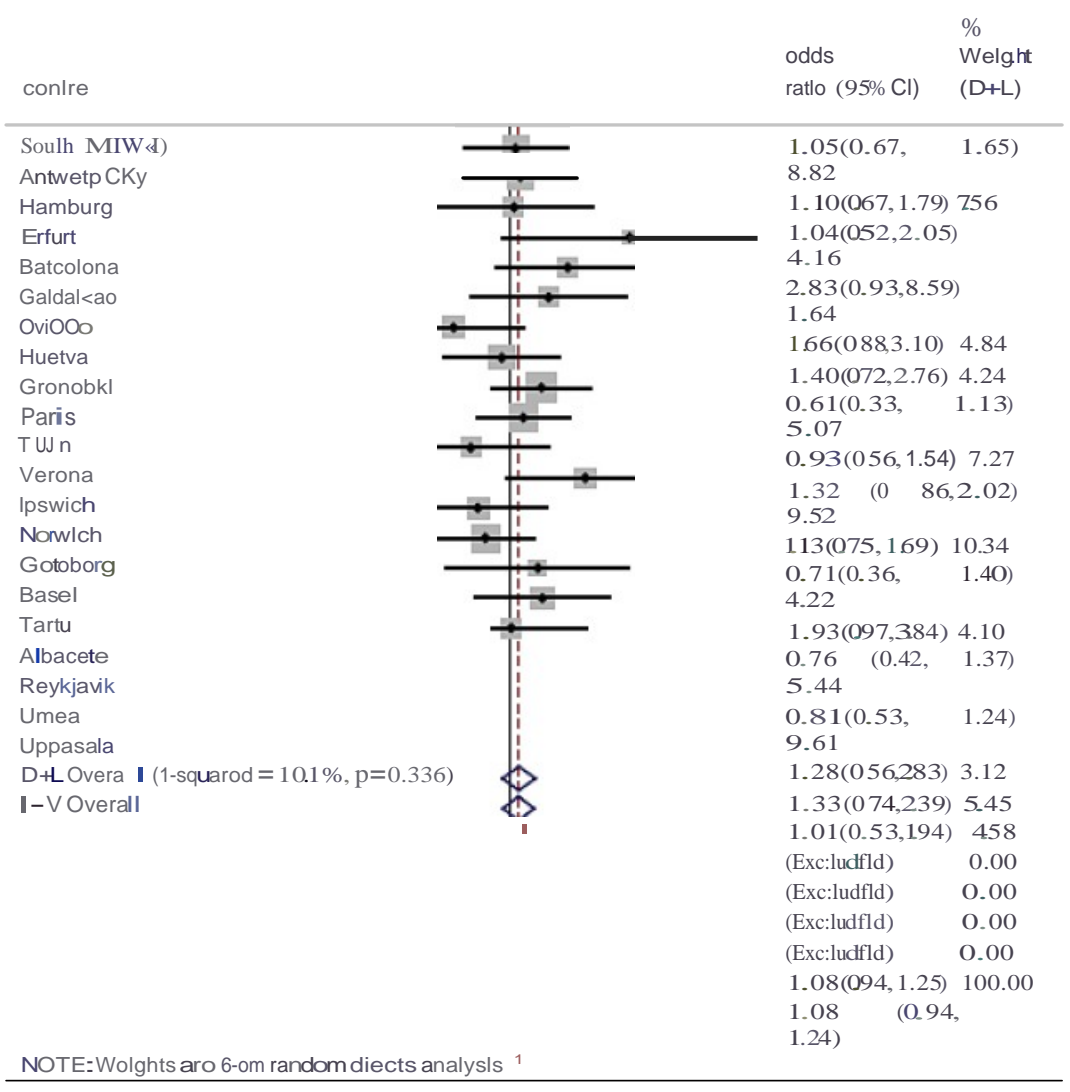

$\begin{array}{lllll}.25 & .5 & 1 & 2 & 10\end{array}$

cut-oft ievel of IgE to $\mathrm{HOM}>0.70 \mathrm{KU} \mathrm{L}$

Tilis is aNIVEL certified Post Print,more info at http://www.nivel.eu 